\title{
PERANCANGAN BUKU KOMIK GEGER CILEGON 1888
}

\section{Mochammad Bagas Ernanto Putra ${ }^{1)}$, Herliyana Rosalinda ${ }^{2)}$, Mochamad Fauzie ${ }^{3)}$}

Program Studi Desain Komunikasi Visual,

Fakultas Bahasa dan Seni, Universitas Indraprasta PGRI

Jl. Nangka No. 58 C, Tanjung Barat, Jakarta Selatan, 12530, Indonesia

Email: bagas.ernanto@gmail.com

\begin{abstract}
Abstrak
Perancangan buku komik Geger Cilegon 1888 ini dibuat sebagai media pembelajaran bagi generasi muda mengenai sejarah perlawanan masyarakat Cilegon melawan diskriminasi Belanda. Pada peristiwa tersebut terdapat penanaman nilai semangat juang dalam jiwa masyarakat, khususnya remaja usia 17 hingga 18 tahun, dalam pembentukan pribadi generasi muda yang nasionalis dan cinta tanah air. Artikel ini akan memaparkan latar belakang serta proses perancangan buku komik Geger Cilegon 1888. Media buku komik dipilih dikarenakan saat ini penjelasan mengenai sejarah peristiwa Geger Cilegon 1888 umumnya berupa buku teks saja, belum ada yang menggunakan media bergambar seperti komik. Media ini akan menjadi salah satu alternatif media yang dapat memvisualisasikan peristiwa Geger Cilegon 1888. Perancangan media ini menggunakan metode kualitatif dengan komponen analisis meliputi: materi komunikasi (materi pesan), analisis khalayak, media komunikasi, komponen-komponen visual yang akan melengkapi data tulisan menjadi data visual. Keunggulan dari media komik secara konsep visual yaitu, masyarakat dapat menikmati media dalam bentuk buku komik dengan cerita yang mudah dipahami, bentuk karakter dan pewarnaan yang menarik sehingga membuat cerita menjadi lebih hidup. Kegunaan dari media hasil rancangan tersebut ialah sebagai salah satu alternatif pilihan media bagi masyarakat yang ingin mengetahui peristiwa Geger Cilegon 1888.
\end{abstract}

Kata Kunci: Buku komik, Geger Cilegon 1888, Sejarah, Perjuangan rakyat.

\begin{abstract}
Design of the comic book Geger Cilegon 1888 was made as a lesson for younger generation regarding history of resistance of the Cilegon people against Dutch discrimination. This incident contained cultivation of the value of a fighting spirit in soul of the community, especially adolescents aged 17 to 18 years in the personal formation of a young nationalist generation who love country (Indonesia). This article will describe the background and process of designing comic book Geger Cilegon 1888. Comic book media was chosen because currently the explanation of history of the Geger Cilegon 1888 incident is generally in form of textbooks only, no one has used pictorial media such as comics. This media will be an alternative media that can visualize the Cilegon Geger 1888 incident. Advantages of comic media in a visual concept are that public can enjoy media in the form of comic books with stories that are easy to understand, interesting character forms and coloring that make the story more interesting. Function of designed this media is as an alternative media choice for people who want to know about the Cilegon Geger 1888 incident.
\end{abstract}

Keywords: Comic book, Geger Cilegon 1888 incident, History, People's struggle.

Correspondence author: Mochammad Bagas Ernanto Putra, bagas.ernanto@gmail.com, Jakarta, and Indonesia 


\section{PENDAHULUAN}

Saat ini buku komik adalah salah satu bacaan yang paling disukai oleh berbagai kalangan. Selain penjabaran cerita yang ringkas namun padat, dalam komik juga terdapat gambar-gambar yang menarik. Menurut Atmakusumah dalam Puspita (2009: 15), kata komik diambil dari bahasa Perancis comique sebagai kata sifat yang berarti 'lucu' atau 'menggelikan', dan sebagai kata benda yang artinya badut atau pelawak. Comique itu sendiri berasal dari bahasa Yunani yaitu komikos. Disebut dengan komik karena pada zaman dahulu cerita komik mengacu kepada ceritacerita humoristis atau satiris untuk menghibur khalayak. Media buku komik sebagai visualisasi dari gambar terjajar dalam urutan yang disengaja, yang bermaksud menginformasikan dan menghasilkan respon estetik serta dirancang untuk memberikan hiburan kepada para pembaca (Mc Cloud, 2010: 7; Supriyanta, 2015: 32). Tujuan utama perancangan sebuah buku komik yaitu untuk memberikan pengetahuan dan menghibur pembaca dengan bacaan yang mudah dipahami. Sejalan dengan hal itu, komik dikembangkan sebagai media untuk menyampaikan pesan penting seperti pengenalan peristiwa-peristiwa sejarah menjadi solusi yang tepat bagi generasi muda untuk tetap memaknai sejarah bangsanya sendiri dan memunculkan nasionalismenya.

Ada beberapa peneliti dan desainer grafis yang telah mengembangkan cerita-cerita sejarah ke dalam media komik, sebagai salah satu tawaran baru pada media pembelajaran di sekolah. Misalnya komik Rengasdengklok yang mendapat respon cukup baik pada kalangan SMA dan SMP (Rosalinda, 2019). Namun belum banyak sejarah peristiwa perjuangan rakyat daerah yang dijadikan komik. Artikel ini merupakan sarian dari penelitian mengenai perancangan buku komik tentang peristiwa Geger Cilegon tahun 1888. Dipilihnya peristiwa sejarah ini karena berisi pesan penting yang dapat dimaknai oleh generasi muda (usia rentang 17 sampai 18 tahun) saat ini, yakni tentang semangat perjuangan, keteguhan berakhlak, beragama, dan bernegara. Peristiwa Geger Cilegon 1888 merupakan sebuah ajakan para tokoh agama Banten yang berhasil menarik dan meyakinkan banyak masyarakat untuk melawan Kolonial Belanda pada saat itu, sedangkan mereka rata-rata tidak terlatih dalam pendidikan militer. Penyerangan tersebut juga memiliki penyusunan strategi yang sangat matang dibandingkan penyerangan pendahulunya. Strategi yang digunakan ialah perumpamaan layaknya bidak permainan catur, di mana semua pemimpin kelompok memiliki peran yang berbeda-beda. Persiapan pun disiapkan secara matang, mulai dari latihan pencak silat dan pengumpulan senjata golok dan tombak yang akan mereka gunakan untuk penyerangan. Saat itu di lain sisi Kolonial Belanda sudah menggunakan senjata api sebagai senjata mereka.

Peristiwa Geger Cilegon 1888 ialah sebuah peristiwa sejarah yang disebut salah satu peristiwa penyerangan masyarakat tani terbesar setelah usainya Kesultanan Banten 1813 oleh VOC dan sebelum terjadinya peristiwa Kaum Tani 1926 di Anyer. Peristiwa tersebut dipelopori oleh beberapa pemuka agama di Banten. Penyebab terjadinya peristiwa tersebut salah satunya dikarenakan unsur keagamaan. Rakyat telah lama berkeinginan untuk merdeka dari penjajahan Belanda, sebab rakyat Banten yang seluruhnya beragama islam merasa semakin tertindas oleh jajahan Belanda. Perjuangan rakyat untuk melakukan pemberontakan juga terinspirasi dari semangat perjuangan pendahulunya, seperti perlawanan Sultan Ageng Tirtayasa, walaupun pada akhirnya itu gagal. Mereka memiliki keteguhan bahwasanya dalam sebuah perang, pastilah terus berkelanjutan, tidak serta-merta menuju pada kemenangan, dan saling menginspirasi.

Rakyat saat itu merasa semakin mendapat peluang untuk mengadakan pemberontakan itu karena munculnya pemimpin baru yang kembali dari Mekkah, yaitu Haji Wasyid. Di Mekkahpun, gagasan yang matang tentang memerdekakan diri dari penjajah sering menjadi tema diskusi. Hal ini ditambah dengan semakin semena-menanya Belanda dalam membuat peraturan untuk rakyat, salah satunya dilarangnya bersalawat dan azan. Pemberontakan ini disebut sebagai Geger Cilegon karena penyerangan pada malam itu membuat geger para Kolonial Belanda di daerah Cilegon, Banten. Peristiwa Geger Cilegon disusun dengan strategi yang matang, dilakukan secara mendadak dan diam-diam tanpa sepengetahuan Belanda, agar penyerangan terhadap Kolonial Belanda tersebut tidak berakhir sia-sia seperti penyerangan-penyerangan terdahulu. Sebelumnya, Banten dilanda wabah kekeringan sekitar tahun 1882 dan 1883. Saat itu, wilayah Banten sudah dalam cengkraman Kolonial Belanda. Pada tanggal 26 Agustus 1883 Gunung Krakatau meletus. 
Semua desa di tepi pantai musnah diterjang air laut, desa-desa lainnya hancur, dan ribuan penduduk mati terbunuh. Kerusakan amat parah terjadi di sekitar Kewedanaan Anyar, sehingga untuk memulihkan roda pemerintahan Belanda, Kantor Kewedanaan dipindahkan ke Cilegon.

Peristiwa ini dimulai ketika Banten dikuasai oleh Belanda. Wilayah Banten merupakan wilayah yang memiliki keagamaan Islam yang kuat. Keseharian masyarakat lekat dengan ibadah salat berjamaah, diramaikannya langgar/ masjid, dihidupkannya tolong-menolong di antara sekampung dikarenakan perbaikan nasib masyarakat saat itu tidak akan diharapkan dari para pemimpin abtenar bangsa yang bergelar Adipati, Patih, Wedana, dan Asisten Wedana yang lebih membela Belanda daripada rakyat. Pada 1885 Belanda juga mendiskriminasi rakyat, salah satunya dengan memusnahkan kerbau sebagai hewan ternak milik rakyat. Hal itu disebabkan karena kerbau merupakan hewan yang menjadi sumber mata pencaharian, yakni sebagai pembajak sawah.

Haji Wasyid dikenal sebagai seorang tokoh yang selalu dekat dengan rakyat. Ia secara gamblang menunjukkan rasa kebenciannya pada Belanda. Sikap karismatik dalam memimpin pemberontakan pada Belanda sangat menarik perhatian rakyat. Sehingga ia dapat menggerakkan pengikutnya (seluruh rakyat Banten) untuk mengadakan pemberontakan (Ansor, 2020: 50). Haji Wasyid tidak terburu-buru melakukan pemberontakan karena ingin memikirkan strategi yang matang. Dari para pendahulunya, terjadi kekalahan demi kekalahan yang selalu menimpa pejuang, diakibatkan antara lain: strategi yang kurang matang, kekuatan pejuang yang kurang memadai, penyerangan selalu pada siang hari (saat Belanda aktif berjaga), para pejuang yang bergerak sendiri-sendiri tanpa sasaran yang jelas, dan persenjataan yang masih tradisional, sedangkan Belanda memiliki persenjataan lengkap yang modern. Tindakan pertama yang ditempuhnya adalah merintis kesadaran para ulama dan rakyat tentang arti kemerdekaan dan memompa semangat juang mereka, serta menekankan pentingnya persatuan dan kesatuan di antara masyarakat (Hamid, 1987: 78).

Pada 1884, perundingan rahasia pertama pun dilakukan di kediaman Haji Wasyid dan berlanjut hingga pertemuan ke enam, yaitu pada 24 Juni 1888. Isi dari enam pertemuan tersebut ialah membahas strategi yang akan mereka gunakan untuk penyerangan, baik dari pembagian kelompok, lokasi jalan yang mereka pilih, dan juga senjata apa yang akan mereka gunakan dalam perjuangan tersebut. Lokasi dari perjuangan tersebut terjadi di sekitaran Banten, meliputi Bojonegara, Beji, Cilegon dan Saneja. Namun, pusat dari penyerangan tersebut ialah Cilegon karena pusat dari pemerintahan Kolonial Belanda berada disana. Pagi 9 Juli 1888, dimulailah perjuangan tersebut. Pemerintahan Belanda dan Amtenar Bumiputra yang menjadi target penyerangan terkejut dengan serangan tersebut. Para pejuang berpencar sesuai rencana. Pukul 8 pagi, para pejuang sudah menguasai kota Cilegon dan berkumpul di gardu pasar.

Tanpa sepengetahuan para pejuang, Bupati Serang, Kontrolir Serang, dan Letnan Van Ser Star membawa pasukan bersenjata lengkap 40 orang. Mereka menuju Kota Cilegon untuk memulai pertempuran di daerah Toyomerto. Pasukan tersebut berhasil memukul mundur para pejuang dengan gugurkan sembilan orang dari pihak pejuang dan sebagian terluka. Hal ini mematahkan moralitas para pejuang. Peristiwa ini membuat setiap pasukan induk pejuang tercerai-berai dan penyerangan pun mulai surut. Sementara itu, karena kedudukan Belanda semakin kuat di Cilegon, Haji Wasyid dan para pasukannya mengurungkan niat untuk menguasai Cilegon dan melakukan long march menuju arah Banten Selatan. Pada 30 Juli 1888, ekspedisi tantara kolonial mengakhiri perjalanan Haji Wasyid dan pasukannya ke daerah Sumur. Para pejuang tetap memberikan perlawanan terhadap tantara kolonial meskipun akhirnya mereka dilumpuhkan.

Pada akhirnya pemimpin-pemimpin perjuanganlah yang menjadi korban dalam pertempuran. Sebagaimana Haji Wasyid sendiri yang jelas bersalah membunuh orang. Setelah melalui proses pemeriksaan dan jelas kesalahannya, beliau dihukum gantung. Pemimpinpemimpin penyerangan yang tidak turut bersalah membunuh orang yang berjuang karena keyakinan, tetap kalah dalam perjuangan tidak dihukum gantung, melainkan diasingkan (Hamka, 2020: 86). Menurut Prabowo (2017) pejuang yang diasingkan berjumlah 94 orang. Tempat pengasingan antara lain: Padang, Tondano, Kupang, Gorontalo, Kema (Minahasa), Salayar, 
Balangnipa (Sinjai), Padang Sidempuan, Ternate, Maros, Ambon, payakumbuh, Muntok, Manado, Banda, Bukittinggi, Bantaeng, Manado, Bengkulu, Pacitan, Pariaman, dan Saparua. Setelah penyerangan berhasil dipadamkan, dikeluarkan sebuah instruksi untuk segenap Amtenar. Kolonial Belanda dan Bumiputra diharapkan selalu berhati-hati menjaga perasaan penduduk muslim. Harus dijaga hati kyai-kyai yang amat berpengaruh kepada pengikutnya. Jangan terburuburu menjalankan sebuah peraturan, sebelum ditinjau kehendak dan perasaan penduduk (Hamka, 2020: 86).

Tokoh-Tokoh Utama dalam Peristiwa Geger Cilegon 1888, yaitu Haji Abdul Karim, Haji Tubagus Ismail, Haji Marjuki dan Haji Wasyid. Tokoh utama dalam perancangan buku komik ini yaitu Haji Wasyid. Haji Wasyid baru tampil sebagai pemimpin perjuangan beberapa tahun sebelum perjuangan itu dimulai. Haji Wasyid merupakan teman dekat dari Haji Tubagus Ismail. Diketahui Haji Wasyid cukup lihai untuk menarik keuntungan dari suasana kebangkitan agama di lingkungannya. Hal ini dilakukan dengan mengidentifikasikan urusan-urusan pribadinya dengan kepentingan bersama masyarakat. Haji Wasyid merupakan orang yang sangat berpengaruh, tidak hanya sebagai guru agama melainkan juga karena kepribadiannya yang kuat. Selain itu, Haji Wasyid dikenal sebagai orang yang mudah terpancing emosi dengan memiliki kecenderungan kepada hal mistik. Haji Wasyid berasal dari keluarga pejuang. Ayahnya, Abas, turut dalam perjuangan Wakhia pada tahun 1850 (Kartodirdjo, 2015: 205; wawancara dengan Asep Softwatullah pada 5 Desember 2019). Haji Wasyid, dilahirkan di Gerogol, Cilegon. Ia merupakan murid dari Syeikh Nawawi Al-Bantani dan tokoh yang menentukan dalam peristiwa Geger Cilegon 1888. Haji Wasyid pernah belajar di Mekkah pada Syeikh Nawawi Al-Bantani, dan mengajar pesantrennya di kampung Beji, Cilegon (Fitriana, dkk, 2016: 20).

Cilegon mempunyai sejarah perjuangan dramatis dalam mengusir penjajah. Namun hal ini terkesan kurang diperhatikan oleh masyarakat, sehingga banyak generasi muda yang tidak mengetahui nilai-nilai luhur dari para pendahulu Kota Cilegon yang patut diteladani (Ilung: 2017). "Geger Cilegon adalah salah satu peristiwa yang masih sangat dihargai oleh Belanda hingga saat ini. Namun, sangat disayangkan kurang dihargai oleh masyarakat kita sendiri. Padahal, peristiwa tersebut merupakan salah satu peristiwa besar yang ada di tanah jawa pada masa itu" (wawancara dengan Asep Softwatullah, 2019). Menurut Fauzan (2013: 34) bahwa peristiwa Geger Cilegon 1888 dapat dijadikan pelajaran living history sebagai upaya membangun nilai nasionalisme dan patriotisme pada siswa. Salah satu contoh dalam peristiwa Geger Cilegon 1888 adalah siswa dapat mempelajari gerakan tarekat-tarekat yang berkembang di daerah sekitarnya. Maka dengan dibuatnya buku komik peristwa Geger Cilegon 1888 ini, tujuan dan harapan di atas dapat tersampaikan dengan baik. Perancangan buku komik ini merupakan sebuah upaya untuk menghidupkan kesadaran pentingnya sejarah Nasional pada generasi muda.

\section{METODE PENELITIAN}

Jenis penelitian ini yaitu penelitian penciptaan atau perancangan dengan metode analisis data secara kualitatif. Dalam ilmu Desain Komunikasi Visual, analisis data dilakukan sekurangkurangnya dengan beberapa komponen informasi atau komunikasi yang meliputi: materi komunikasi (materi pesan), analisis khalayak, media komunikasi, komponen-komponen visual yang akan melengkapi data tulisan menjadi data visual. Penelitian kualitatif secara umum dapat digunakan untuk penelitian tentang kehidupan masyarakat, sejarah tingkah laku, fungsionalisasi organisasi, aktivitas sosial, dan lain-lain. Salah satunya adalah sejarah peristiwa Geger Cilegon pada tahun 1888 yang pada penelitian ini menggunakan buku Tragedi Berdarah Banten 1888 sebagai acuan utama, wawancara dengan Asep Softwatullah selaku ketua Yayasan Haji Wasyid sekaligus cicit dari Haji Wasyid yang merupakan tokoh penting dalam peristiwa Geger Cilegon 1888, serta observasi lapangan ke Rumah Dinas Walikota Cilegon yang berlokasi di Jalan Ahmad Yani, Jombang Wetan, Kecamatan Cilegon, Kota Cilegon, Banten, dan juga di Menara Masjid Baitul Mutaqin yang berlokasi di L. Ki Yasin Beji Kampung Gunung Santri, Bojonegara, Serang, Banten. Salah satu alasan menggunakan pendekatan kualitatif karena metode ini dapat digunakan untuk menemukan dan memahami apa yang tersembunyi dibalik fenomena yang kadangkala merupakan sesuatu yang sulit untuk dipahami. Maka dari itu, mendeskripsikan peristiwa Geger 
Cilegon 1888 dilakukan dengan menggunakan analisis data kualitatif, dan juga pendekatan tersebut dijadikan acuan dalam merancang media buku komik.

\section{HASIL DAN PEMBAHASAN}

\section{Konsep Dasar Perancangan Buku Komik}

Konsep perancangan dari buku komik terdiri dari analisis khalayak, dan konsep visual media untuk membuat rancangan buku komik Peristiwa Geger Cilegon 1888.

\section{Analisis Khalayak}

Analisis khalayak meliputi segmentasi (wilayah demografis, dan psikografis) dan positioning. Wilayah meliputi Provinsi Jawa Barat yang difokuskan pada kota Cilegon dan Banten. Segmentasi berdasarkan demografi meliputi usia remaja akhir (17--18 tahun), jenis kelamin laki-laki dan juga perempuan, dan pendidikan tingkat SMA memasuki masa sekolah kelas 11 dan 12. Segmentasi pada psikografis adalah remaja yang memiliki minat tinggi pada sejarah, terutama sejarah daerah mereka sendiri, dan juga remaja yang menyukai media buku komik yang bertemakan tentang pahlawan atau sejarah. Positioning pada perancangan ini ialah masyarakat yang ada di daerah Cilegon dan Banten, khususnya remaja pada sosial ekonomi menengah, yang kurang atau bahkan tidak mengetahui jalan cerita peristiwa Geger Cilegon pada tahun 1888. Pesan yang dapat disampaikan ialah dengan melihat perjuangan tersebut, masyarakat lebih menghargai sejarahnya sendiri dan dapat menanamkan tekad perjuangan, bahwa perjuangan tersebut merupakan bentuk keberanian masyarakat pada saat itu hingga muncul perlawanan untuk menghentikan diskriminasi Belanda yang semena-mena dan kejam.

\section{Konsep Media (Buku Komik)}

Komik merupakan salah satu media yang menampilkan cerita secara visual melalui gambar dalam panel, yang dilengkapi dengan teks narasi atau dialog dalam balon-balon kata. Buku komik terdiri dari beberapa unsur, di antaranya; halaman pembuka, halaman isi, sampul komik, Splash Page (Halaman pembuka yang berisi judul, kreator, cerita, dan ilustrator), dan Double-spread page (dua halaman penuh, untuk memunculkan kesah dramatis, dasyat, atau sengaja ditampilkan gambar khusus agar pembaca terbawa suasana).

Perancangan ilustrasi karakter pada tokoh buku komik mendapatkan referensi dari fotofoto pada tahun 1888 dan dari segi pakaian sesuai dengan pakaian pada masa itu. Pada saat peristiwa itu terjadi rata-rata pejuang mengenakan baju putih dan membawa senjata golok. Ilustrasi dari buku komik tersebut yang nanti dibuat dengan cara konvensional lalu dipadukan dengan komputer grafis. Langkah awal yaitu pembuatan sketsa, kemudian ditebalkan, lalu pewarnaan dengan komputer menggunakan software Clip Studio Paint EX. Skema warna yang digunakan didominasi dengan warna putih, krem, biru tua, abu-abu, dan hitam. Warna putih dipilih karena sebagian besar karakter menggunakan pakaian berwana putih, sedangkan krem adalah warna kulit. Warna cream yang digunakan warna turunan mulai dari itu krem gelap hingga terang untuk warna kulit orang Belanda. Warna biru tua digunakan untuk menggambarkan latar langit malam. Warna hitam digunakan untuk efek shading dan outline dari gambar.

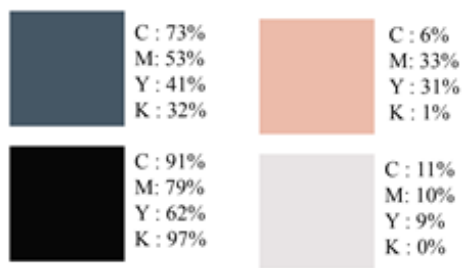

Gambar 1 Skema Warna 
Pemilihan huruf juga merupakan suatu hal yang penting untuk dipilih, manakah huruf yang tepat. Tujuannya, ketika pembaca melihat hasilnya, buku komik ini mudah untuk dipahami dan tidak keluar dari konsep yang telah ditentukan sebelumnya. Pemilihan huruf yang dimaksud seperti untuk pemilihan huruf judul komik, dan untuk balon teks dalam komik. Jenis huruf yang digunakan dalam perancangan ini untuk judul komik adalah jenis huruf serif yaitu Roman SD.

\section{ABCDEFGHIJKLMN \\ OPQRSTUVWXYZ \\ $1234567890 ;:$, \\ ROMAN SD}

Gambar 2 Huruf Roman SD

Bagian isi komik menggunakan jenis huruf Sans Serif yaitu Anime Ace 2.0. Jenis tulisan ini dipilih karena jelas dan rata-rata isi komik manga Indonesia menggunakan jenis huruf tersebut.

\section{$\triangle B C D E F G H I U K L M N$ \\ OPQRSTLVWXYZ \\ $1234567890 ;:, "$ \\ ANIME ACE 2.0}

Gambar 3 Huruf Anime Ace 2.0

\section{Perancangan Media}

Judul buku komik ini yaitu Geger Cilegon 1888. Berikut ini adalah desain dari judul buku komik "Geger Cilegon 1888".

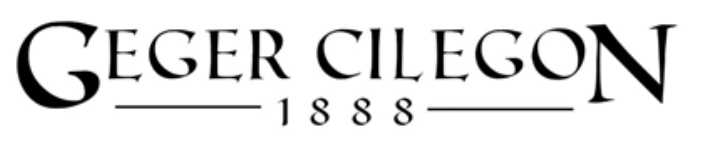

Gambar 4 Judul Buku Komik

Cover atau sampul depan memperlihatkan salah satu pemuka agama yang menjadi tokoh utama dalam Komik ini. Yaitu Haji Wasyid.

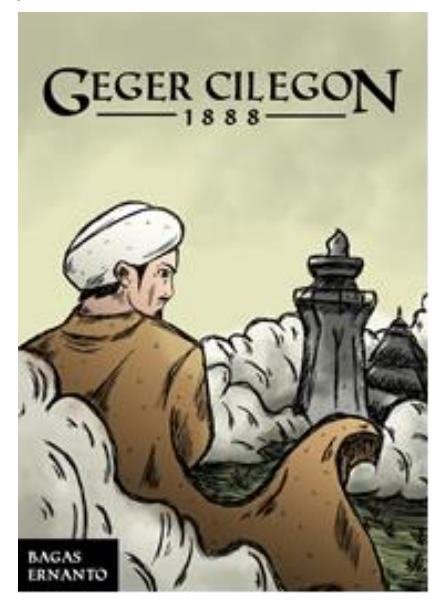

Gambar 5 Cover Buku Komik Geger Cilegon 1888 
Desain karakter meliputi ilustrasi tokoh Haji Wasyid, Haji Tubagus Ismail, Pejuang, Francois Dumas, dan Prajurit Belanda.

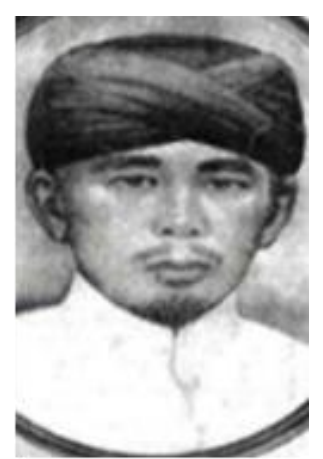

(1)

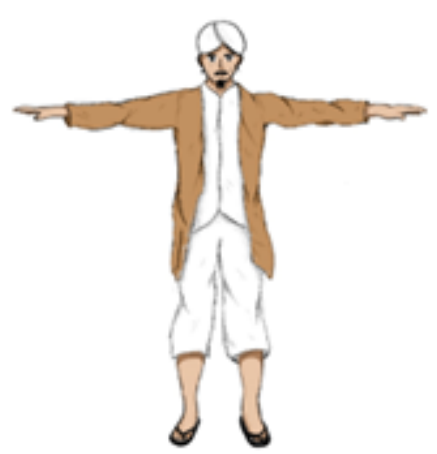

(2)

Gambar 6 (1) Wajah Asli Haji Wasyid. (2) Ilustrasi Karakter Haji Wasyid

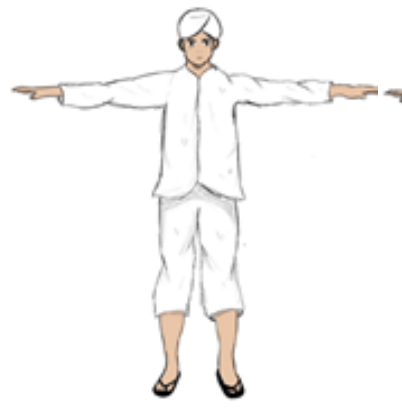

(1)

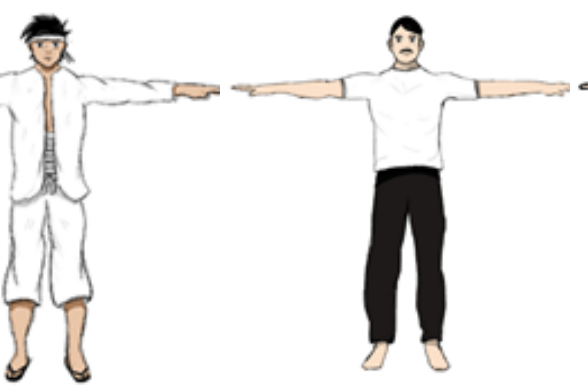

(2)
(3)

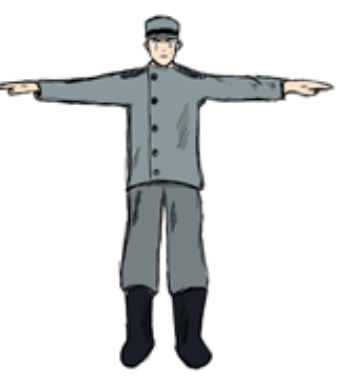

(4)

Gambar 7 (1) Ilustrasi Karakter Haji Tubagus Ismail, (2) Ilustrasi Karakter Pejuang, (3) Ilustrasi Karakter Francois Dumas, (4) Ilustrasi Karakter Prajurit Belanda

\section{Hasil Perancangan}

Pada perancangan buku komik Geger Cilegon 1888 ukuran yang digunakan yaitu A4. Menggunakan teknik cetak digital printing. Bahan kertas isi adalah art paper 150gsm, dan art carton 260gsm sebagai bahan untuk sampul buku. Seluruh bagian komik dicetak berwarna. Sampul buku menggunakan teknik cetak laminasi doff dan teknik jilid yang digunakan adalah jilid staples.

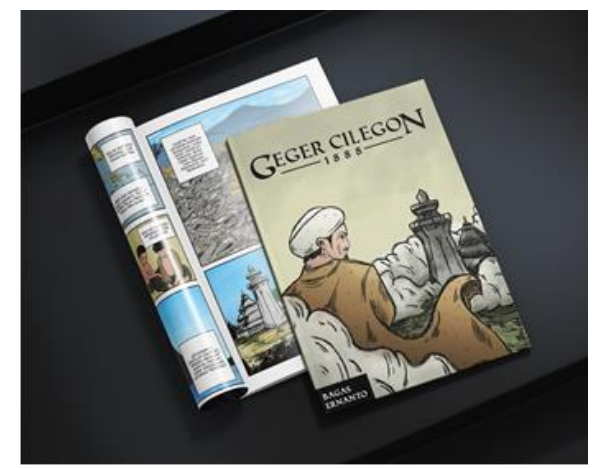

Gambar 8 Mockup Hasil Komik Geger Cilegon 1888 
Berikut adalah hasil perancangan buku komik Geger Cilegon 1888 yang meliput: Bagian Awal, Bagian Isi, dan Bagian Penutup.

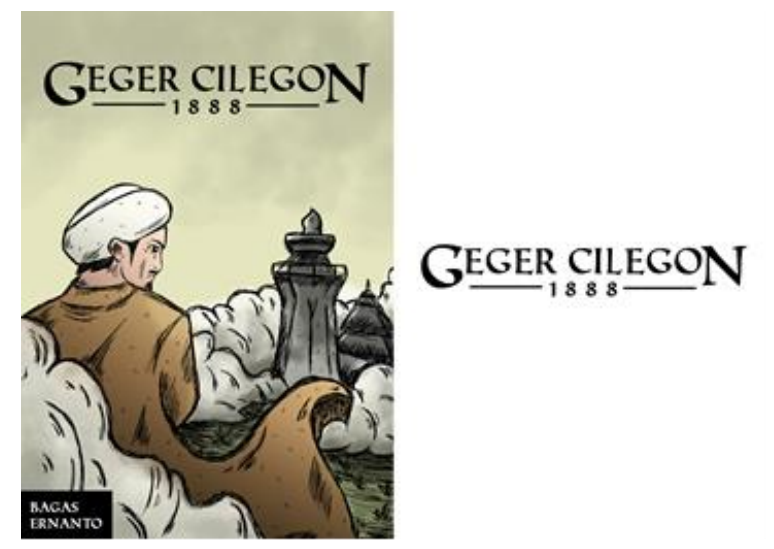

Gambar 9 Bagian Awal; Cover \& Judul Awal Komik Geger Cilegon 1888
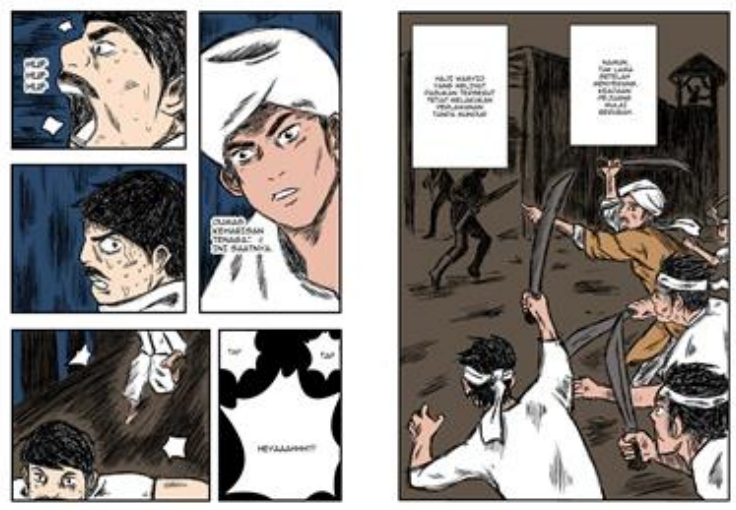

Gambar 10 Bagian Isi Komik Geger Cilegon 1888
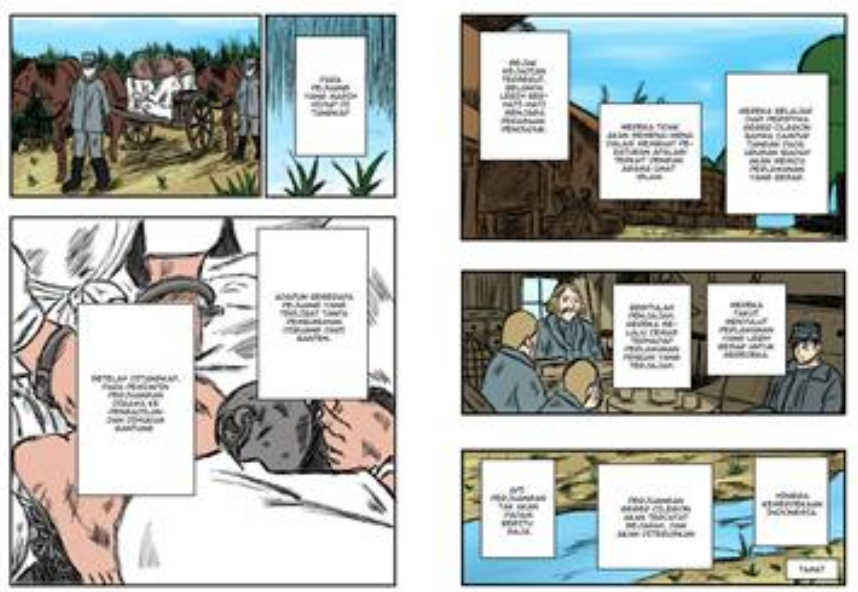

Gambar 11 Bagian Penutup Komik Geger Cilegon 1888

\section{SIMPULAN}

Dirancangnya buku komik Geger Cilegon 1888 adalah sebagai salah satu media informasi secara visual yang membahas tentang sejarah daerah sebelum kemerdekaan khususnya untuk daerah Banten. Buku komik menjadi media yang dapat menginformasikan peristiwa Geger 
Cilegon 1888 dengan cara lebih kreatif, sehingga bisa menarik minat khalayak. Visual yang dimuat dalam buku komik merupakan hasil visualisasi dari obervasi perancang Geger Cilegon 1888, sehingga pembaca buku komik dapat lebih mudah mengerti kondisi peristiwa pada masa itu. Buku Komik Geger Cilegon 1888 merupakan media informasi yang membahas tentang peristiwa Geger Cilegon mulai awal hingga akhir dari peristiwa tersebut. Mulai dari awal penyebab peristiwa, penyusunan rencana, puncak peristiwa, hingga akhir dan hasil dari peristiwa tersebut. Buku Komik termasuk salah satu kategori dari desain komunikasi visual, maka buku komik dipilih sebagai media informasi untuk menyampaikan pesan secara lebih kreatif dan informatif. Visualisasi yang tertuang dalam buku komik merupakan gambaran dari kondisi peristiwa pada masa itu, sehingga pembaca dapat lebih mudah mencerna informasi yang disajikan dalam bentuk buku komik.

\section{DAFTAR PUSTAKA}

Ansor, A. S., \& Muttahidah, M. (2020). Kepemimpinan Kiai Wasyid dalam memimpin pemberontakan Geger Cilegon 1888. Islamic Management: Jurnal Manajemen Pendidikan Islam, 3(02), 47-73.

Fauzan, R. (2016). Penerapan Model Pembelajaran Living History Dalam Materi Sejarah Lokal Geger Cilegon 1888 Sebagai Upaya Membangun Nilai Patriotisme Siswa. Candrasangkala: Jurnal Pendidikan dan Sejarah, 2(2), 24-37.

Fitrina, E., Suwirta, A., \& Kamsori, E. (2016). Perjuangan Syeikh Nawawi Al-Batani dalam melawan kolonialisme di Banten (1831-1897). Factum, 5(1), 13-32.

Hamid, A. (1987). Tragedi berdarah di Banten 1888. Serang: Yayasan Ki Haji Wasyid.

Hamka. (2020). Dari perbendaharaan lama. Gema Insani.

Ilung (2017) Meng-Ulang Tahuni Cilegon dengan seutuhnya [Forum Online]. Diakses dari http://faktabanten.co.id/meng-ulang-tahuni-cilegon-dengan-seutuhnya/.

Kartodirdjo, S. (2015). Pemberontakan Petani Banten 1888. Komunitas Bambu.

Mcloud, S. (2010). Reinviting Comics. PT. Gramedia Pustaka Utama.

Prabowo, G.A. (2017) Kisah pemberontakan rakyat "Geger Cilegon 1888” [Online]. Diakses dari http://www.berdikarionline.com/geger-cilegon-1888/.

Puspita, M.D. (2009). Komik sebagai koleksi perpustakaan umum Kotamadya Jakarta Pusat. (Skripsi). Program Studi Ilmu Perpustakaan dan Informasi, Fakultas Adab dan Humaniora, Universitas Islam Negeri Syarif Hidayatullah Jakarta.

Rosalinda, H. (2019). Nilai nasionalisme dalam komik: Kajian semiotika komik Rengasdengklok. Jurnal Desain. 6 (2), 89-98.

Supriyanta, E.Y. (2015) Pengembangan media komik untuk mata pelajaran ilmu pengetahuan sosial tentang sejarah persiapan kemerdekaan Indonesia pada kelas V SD Muhammadiyah Muthian Wates Kulon Progo. (Skripsi). Jurusan Pendidikan Prasekolah dan Sekolah Dasar, Fakultas Ilmu Pendidikan, Universitas Negeri Yogyakarta. 